\title{
RUSIJA „LIETUVIỤ KALBOS ŽODYNO“ ILIUSTRACINIUOSE SAKINIUOSE IR REIKŠMIŲ APIBRĖŽTYSE
}

\author{
Aurelija GRITÉNIENÉ \\ Lietuviu kalbos institutas
}

\section{Ivadas}

Didysis „Lietuvių kalbos žodynas“ (toliau tekste LKŽe) - 100 metų rašytas didžiausias lietuvių kalbotyros veikalas, kurị pagrịstai galime vadinti savotišku lietuvių tautos epu. İ ši žodyną galima žvelgti kaip ị įvairialypi tekstyną, kuriam medžiaga buvo renkama iš 445 rašytinių ir rankraštinių šaltinių ir 492 vietovių iš visų lietuvių kalbos tarmių. LKŽe nuo kitų lietuvių kalbos aiškinamųjų žodynų skiriasi savo apimtimi, istoriškumu ir tarminès medžiagos gausa. Būtent dèl to šis žodynas laikomas vienu svarbiausių XX a. pirmosios pusès lietuvių kultūros tekstų. Tai unikalus šaltinis, teikiantis daugybę galimybių bei impulsų naujoms įžvalgoms (Zabarskaitė 2012: 241). Ne veltui žodynai (taip pat tautosakos rinkiniai, istoriografiniai veikalai) laikomi tautos požymių kompendiumais (Subačius 1999: 34).

Remiantis akademinio žodyno kaip ịvarialypio tekstyno medžiaga jau ištirtas lietuviu politinis pasaulėvaizdis (valstybè, įstatymas, valdžia), pasitelkus žodyne fiksuotą Adalberto Bezzenbergerio medžiagą, aprašytos marios, pamarys ir pamariškis (Zabarskaite 2010: 126tt; 2012: 239tt); nagrinètas šermukšnio ir žodyno vaizdinys (Gritenienè 2016: 85tt; 2017: 1tt); tirta, kokia terminologinè informacija atrinkta žodynui, ką sako iliustraciniai pavyzdžiai terminologijos klausimais (Umbrasas 2019: 162tt).

Šio straipsnio tikslas - ištirti, koks RUSIJOS konceptas susidèlioja iš LKŽe iliustracinių sakinių ir reikšmių apibrèžčių, kuriose minima leksema Rusija, nustatyti, kurie koncepto požymiai yra svarbiausi, ryškiausi ${ }^{1}$ ir kokia galètų būti Rusijos kognityvinè definicija². Siekiant ịgvendinti pagrindini

1 Konceptas - tai vaizdinys, iškylantis mūsų sąmoneje išgirdus ar pamačius parašytą žodị. Jis suvokiamas kaip esminis pažintinis žinių vienetas, priklausantis žmogaus konceptualiajai sistemai ir kylantis iš patirties - tai yra visa informacija apie ką nors, esanti žmonių, kalbančių tam tikra kalba, sąmonèje (plačiau žr. Papaurèlytė-Klovienė 2007: 17; Gudavičius 2011: 109tt; Smetonienè 2019: 131).

2 Kognityvinė definicija veikia kaip metodas stereotipams ir jų vidinei struktūrai aprašyti. Ji remiasi kasdieniu, asmeniniu pasaulio pažinimu ir patyrimu; ja siekiama parodyti, kokių asociaciju kyla kalbėtojo sąmonejje tam tikroje kalbinejje situacijoje (Bartmiński 2007: 44; Gudavičius 2009: 70tt; Rutkovska, Smetona, Smetonienè 2017: 30; Smetonienè 2019: 132). 
tyrimo tikslą, iškelti keli konkretūs uždaviniai: ištyrus surinktą medžiagą semantinès analizès, interpretaciniu ir aprašomuoju metodais, apibūdinti Rusijos svarbiausius įvykius, ekonomiką, ūkį, ryšĭ su Lietuva, aptarti šalyje gyvavusias idejjas, partijas, socialines grupes, žmonių ir tautų padètị, apibūdinti šalies gamtą, mokslą ir meną. Straipsnyje analizuojami ne žodžių tarpusavio santykiai junginyje ir ne atskiri žodžiu junginiai, o žiūrima, kokia svarbi konceptuali informacija pasakoma visu sakiniu, kai per konkretaus žodžio semantiką ir ryšius su kitais žodžiais, reikšmėmis, konotacijomis, asociacijų semantinius mechanizmus sukuriama aukščiausia kalbos suvokimo pakopa - prasmè, kartu su ja ir ideologinè implikacija, daranti įtaką tam tikro objekto vertinimui (plg. Zabarskaite 2019: 76tt). Taigi straipsnyje laikantis kognityvinio požiūrio bandoma nustatyti, kaip kalbos vartotojų sąmonejje verbalizuojamas RUSIJOS konceptas.

Tyrimui toks konceptas pasirinktas tikslingai. Lietuvos valstybė įsikūrusi teritorijoje, kurioje susikerta Rytu ir Vakarų interesų sferos, tad akivaizdu, kad bene didžiausią įtaką Lietuvos ,politiniam ir kultūriniam gyvenimui, jos valstybingumo raidai nuo XV a. pabaigos dare rytų kaimynè - Maskvos kunigaikštystė, vẻliau carinė Rusija, o nuo XX a. Sovietų Sąjunga“ (Burinskaitė 2005: 9). Net ir subyrëjus šiai sąjungai, Vakarai (tame tarpe ir Lietuva) negali apsieiti be Rusijos. Šiandienos istorikai ne veltui šią valstybę vadina imperija, teigdami, kad imperijos, valdè ir valdys pasauli, o Rusija šiame „,imperijų koncerte" užima svarbią, esminę vietą (Nowak 2015: 285). Kalbininkai jau yra ištyrę ir aprašę Rusijos federacijos prezidento Vladimiro Putino naratyvų ideologinius mechanizmus Lietuvos internetinèje žiniasklaidoje (Zabarskaitė 2019: 76tt), ne mažiau įdomu pasižiūrèti, kokią vietą pati Rusija užima lietuvio pasaulèvaizdyje, koks jos paveikslas susidèlioja akademinio žodyno kontekste, kuriame sutelktas pasaulis Lietuvoje ir Lietuva visame pasaulyje (Nepokupnas 2002: 1421).

Straipsnyje išanalizavus vieno konkretaus žodžio (ir jo sinonimų) vartoseną taip pat bandoma nustatyti, ar yra (ne)paslèptos ideologijos LKŽe diskurse. Skaitant akademinį žodyną būtina nepamiršti, kad sovietinès okupacijos metu jis neišvenge to meto režimo primestos sovietinès cenzūros bei ideologinio kišimosi ị žodyno turinį. 1947 m. išẻjus Juozo Balčikonio redaguotam II žodyno tomui po metų spaudoje pasirodè žodynininko (vèliau - vieno iš vyriausiųiu žodyno redaktorių) Jono Kruopo recenzija, kurioje jis, prisitaikydama prie to meto aplinkybių, teigè, kad ,žodynas negali būti apolitiškas ir beidejiiškas. Jis, kaip ir kiekvienas tarybinis mokslo veikalas, turi turèti vieną pagrindinį tikslą - tarnauti liaudžiai, prisidèti prie visuomenès komunistinio auklejimo, prie buržuazinių liekanų iš žmonių sąmonès išgyvendinimo“ (Kruopas 1948: 45). 
Po daugelio metų buvęs Lietuvių kalbos ir literatūros instituto direktorius prisiminè, kad anuo metu šis J. Balčikonio redaguotas tomas „sukèlė dideli nepasitenkinimą partijos Centro komitete, tomas buvo išimtas iš apyvartos ir sunaikintas, išlikę egzemplioriai tapo bibliografine retenybe“ (Žukas 2005: 56). Taigi I ir II tomai buvo „perrašyti“ pagal sovietinių mokslo ideologu modelį․ Buvo siekiama, kad žodynas taptų socialistinès sąmonès įtvirtinimo pagrindu, tarnautų liaudžiai, prisidètų prie socializmo statybos ir komunistinio visuomenès auklèjimo, todèl nuo trečio tomo buvo pakeista žodyno rašymo instrukcija ${ }^{4}$, pirmieji du tomai paslèpti specfonde (Tamulionienè 2003: 63; Zabarskaitė 2010: 127). Net 14 žodyno tomų buvo leidžiami sovietų okupacijos metais, XV tomas išejo $1991 \mathrm{~m}$., tad jis mažiau paveiktas sovietinès ideologijos, „nuo XVI tomo žodyne sumažèjo ideologinès medžiagos, o po nepriklausomybės atkūrimo jos visai nebeliko" (Zabarskaitė 2010: 128). Taigi didžioji dalis žodyno buvo cenzūruojama pagal griežtą ideologinį modelį, kelis dešimtmečius sakiniai iš įvairių rašytinių šaltinių ir gyvų istorijos liudininkų buvo renkami ir užrašomi veikiant (savi)cenzūrai, kuri vykdė sovietizaciją ir nepageidaujamą realybę keitė dirbtinai sukonstruota. Nors žodyne rasime nemažai socialistinei sąmonei ugdyti ir ịtvirtinti skirtų iliustracijų, žymimų santrumpa sov. ${ }^{5}$, vis tiek negalime paneigti fakto, kad net ir anuomet „mokslui buvo svarbiausi tarmių ir senųjų tekstų faktai, gyvi sakiniai, ryškinę tautos gyvenimą, mąstymą“ (Vitkauskas 2002: 11). Autentiška žodyno medžiaga atspindi to laikotarpio žmonių jausmus ir mąstymą bei patvirtina mintį, kad žodyną „galima skaityti ir kitaip“ (Zabarskaitė 2012: 241), kaip populiaru istorijos vadovèlį, kuriame išryškejja ne tik istorinis kontekstas, bet ir atitinkamo meto įvykiai, dramos, veikejjai, draugai ir priešai.

3 I ir II žodyno tomų iliustraciniuose sakiniuose Rusija paminèta tik kartą, todèl atskirai peržiūrèti J. Balčikonio redaguotų tomų ir lyginti juos su perleistais sovietmečiu nèra prasmès.

41952 m. parengta žodyno rašymo ir redagavimo instrukcija buvo pildoma ir tikslinama ne kartą (ji perleista 1963 ir 1980 m.) ,atsižvelgiant ị tarybinès leksikografijos teoriją bei praktiką“" (LKŽ instrukcija 1980: 2).

5 Net 18 tyrimui atrinktų LKŽe iliustracinių sakinių turi pažymą sov. Ši pažyma ịvesta rengiant pirmą elektronini LKŽe variantą 2005 m. (vèliau žodynas atnaujintas 2008 ir 2018 m.). Kadangi žodynas buvo rengiamas septynis dešimtmečius, per tą laiką ne kartą keitėsi žodyno sudarymo ir redagavimo principai, tačiau rengiant elektroninę žodyno versiją leksikografiniai straipsniai iš esmès nebuvo redaguojami ar kupiūruojami, ištaisytos tik didesnès pastebėtos antraštinių žodžių transponavimo klaidos, suvienodinti sutrumpinimai, peržiūrètas frazeologizmų pateikimas, adaptuoti leksikografinio pateikimo ir formos dalykai bei kt. Santrumpa sov. elektroninèje versijoje buvo pažymèti ryškiausi sovietizmai, sovietinès realijos (plačiau žr. Naktinienè 2012: 93), tačiau analizuojant tyrimui atrinktus pavyzdžius pastebèta, kad šios pažymos dar trūksta prie daugybès sovietiniu laikotarpiu užrašytų iliustracijų. 
Tiriamoji medžiaga buvo renkama iš $\mathrm{LKŽ} \mathrm{e}^{6}$ : atlikus žodyne detaliąją paiešką rasti 138 iliustraciniai sakiniai, kuriuose minima leksema Rusija ${ }^{7}$. LKŽe Rusija vadinama ir kitais vardais. Rasta 11 iliustracijų, kuriose minima Maskolija ${ }^{8}$, 14 sakinių pavartotas fonetinis Rusijos variantas Rosija ${ }^{9}$, užrašyta po 1 sakinị su Rasiejumi ir Rasieja ${ }^{10}$.

Medžiaga tyrimui rinkta iš LKŽe, neimant naujausių Papildymų ir Tarmių kartotekų duomenų, todèl būtina pabrèžti, kad straipsnyje gauti rezultatai atspindi RUSIJOS konceptą, susidèliojusį lietuvių pasaulèjautoje pradedant Spalio revoliucjos įvykiais ${ }^{11}$ ir baigiant Sovietų Sąjungos žlugimu ${ }^{12}$. Tokị pasirinkimą nulèmė pati žodyno medžiaga: iš senesnių rašytinių šaltinių sakinių su leksema Rusija LKŽe fiksuota visai nedaug (tik 27) ${ }^{13}$, o carinès Rusijos konceptas jau atskirai aprašytas ${ }^{14}$, todèl šiame straipsnyje išsamiau analizuojama, koks Rusijos vaizdinys susidèliojo lietuvių sąmonèje sovietinio laikotarpio kontekste.

Pirminiame medžiagos rinkimo etape iš viso tyrimui buvo atrinkti 165 iliustraciniai sakiniai, kuriuose minima Rusija, Rosija, Rasiejus, Rasieja ir Maskolija. Iš šios imties eliminuota 20 sakinių, kuriuose minima carinè Rusija, ir 27 sakiniai, išrašyti iš senesnių rašytinių šaltinių (XIX-XX a. pradžios). Taigi šiame straipsnyje iš viso analizuojama 118 sakinių, kurių turinys leidžia sudèlioti sovietmečiu lietuvių sąmonėje susiformavusį RUSIJOS konceptą.

${ }^{6}$ Medžiaga rinkta iš 2018 m. atnaujintos LKŽe versijos (žr. www.lkz.lt).

${ }^{7}$ I šią imtį neįtrauktos iliustracijos su leksema Rusia, nes tai istorinis rytų slavų žemių pavadinimas.

8 Iš 11 LKŽe rastų sakinių su Maskolija tik 1 užrašytas gyvojoje kalboje (Šãtėse), o likę 10 fiksuoti Simono Daukanto raštuose bei įvairiuose XIX a. rašytiniuose šaltiniuose: laikraščiuose „Aušra“, „Lietuviška Ceitunga“, „Tiesos prietelius“ ir kt. Maskolija paminèta ir vienoje reikšmès apibrèžtyje - apibrèžiant būdvardị maskolinis 'nuo Maskolijos pučiantis, rytinis (apie vèją)'.

${ }^{9}$ Rosija daugiausia paplitusi šiaurès žemaičių šnektose (apie Kuršénus, Luõkę, Endriejãvą, Raudénus, Šatès); po vieną kitą sakinį su šiuo variantu užrašyta iš pietų, rytų bei vakarų aukštaičių patarmių.

10 Šie variantai fiksuoti Drùskininkuose ir Nemenčinèje.

11 Toks atspirties taškas pasirinktas todèl, kad ši revoliucija laikoma Sovietų Sąungos susikūrimo proceso pradžia, nors oficialiai Sovietų Sąjunga buvo įkurta $1922 \mathrm{~m}$.

12 Primintina, kad dauguma LKŽe iliustracinių pavyzdžių surinkta maždaug iki XX a. vidurio (Zabarskaitė 2012: 247).

13 Daugiausia sakinių rasta šiuose šaltiniuose: „Aušroje“ (4), Vinco Kudirkos ir Antano Smetonos raštuose (po 3), Vinco Pietario ir Juozo Tumo-Vaižganto kūriniuose (po 2), laikraščiuose „Keleivis“, „Tiesos Prietelius“, „Vilniaus žinios“, „Tèvynės sargas“ (po 2), po 1 sakini užrašyta S. Daukanto, Antano Baranausko ir kt. raštuose.

14 Plačiau žr. Gritenene 2020: 273-283. 
Daugiausia apie Rusiją sovietiniu laikotarpiu buvo kalbama įvairiuose rašytiniuose šaltiniuose ${ }^{15}$ - LKŽe rasti 75 tokie sakiniai. Konkrečių rašytojų, mokslo, kultūros veikëjų raštuose rasti tik 9 sakiniai, kuriuose paminèta Rusija (3 sakiniai iš Gabrielès Petkevičaitės-Bitès veikalų, 2 iš Vinco MykolaičioPutino raštų, po 1 sakini fiksuota botaniko Jono Dagio, istoriko ir visuomenininko Petro Klimo, rašytoju Antano Vienuolio ir Ievos Simonaitytès kūriniuose). 6 sakiniai išrašyti iš spaudos: popieriniame žodyne santrumpa sp atsirado tik nuo XVI tomo, o vèliau, rengiant elektroninį žodyno leidimą, ja buvo pažymèti visi vèlesni XX a. periodiniai leidiniai ${ }^{16}$. Iki tol visa tarybinė spauda buvo žymima bendra santrumpa tsp, o ideologiškai svarbesni to meto laikraščiai ar žurnalai turejo savo atskiras santrumpas ${ }^{17} .8$ tyrimui reikalingos iliustracijos didžiajam žodynui buvo išrašytos iš įvairių enciklopedijų, žodynų ir chrestomatijų. Bendrą rš santrumpą turi 53 tyrimui atrinkti sakiniai. Iki XVI tomo marksizmo-leninizmo klasikų raštų vertimai buvo žymimi kaip atskiri šaltiniai rašant visą veikẻjo pavardę, pavyzdžiui, Engelsas, Marksas; šalia Vladimiro Lenino pavardès būdavo nurodomi jo veikalo leidimo metai ir puslapis; ryškiausių sovietinès propagandos skleidejų (rašytojų, visuomenininkų ir pan.) raštai žodyne turèjo atskiras santrumpas, pavyzdžiui, Aleksandras Gudaitis-Guzevičius (A. Gud-Guz), Vincas Kapsukas-Mickevičius (V. Kaps), Valerija Valsiūnienė (V. Vals), Juozas Žiugžda (J. Žiugž) ir kt. Nuo XVI tomo šių ideologinių veikejų pavardès iš žodyno santrumpų sąrašo dingo, jas pakeitė bendra rš santrumpa, vartojama ir elektroniniame žodyno variante ${ }^{18}$. Tarmèse fiksuoti tik 43 sakiniai, kuriuose minima Rusija ir jos sinonimai. Kadangi rašytiniuose šaltiniuose Rusija ir jos sinonimai minimi gerokai dažniau nei užrašytuose iš gyvosios kalbos, galètume teigti, kad LKŽe pirmiausia išryškejja i̇vairių rašto žmonių (publicistų, žurnalistų, rašytojų, politikų ir pan.), kultūros bei visuomenès veikèjų sudèliotas RUSIJOS konceptas.

Atskiros LKŽe iliustracijos autorius yra individualizuotas (iliustracinio sakinio pabaigoje nurodoma konkretaus asmens, iš kurio raštų imtas sakinys, pavardès santrumpa, pavyzdžiui, A. Vien, Pt, P. Klim ir kt.) arba anoniminis (tokių iliustracijų autorių slepia bendros rš, sp, LE, MLTE ir pan. santrumpos). Tačiau bendrąja prasme galime teigti, kad visą žodyno hipertekstą kūrẻ vienas

${ }^{15}$ Apie LKŽe šaltinius kaip kultūros istorijos atspindžius plačiau žr. Šimėnaite 2010: 158tt.

16 Pirmieji XIX a. lietuviški laikraščiai („Aušra“, „Lietuviška Ceitunga“ ir kt.) atskiras santrumpas turèjo visą laiką.

17 Kaip atskiri šaltiniai žodyne buvo išskirti „Komunisto“ ir „Tiesos“ leidiniai, jų pavadinimai sovietmečiu žodyno tekste net nebuvo trumpinami.

18 Kadangi medžiaga tyrimui buvo renkama iš elektroninès žodyno versijos (nes čia veikia įvairios automatinès paieškos), tai ir pačiame straipsnyje prie iliustracijų paliktos bendrosios santrumpos sp bei ršs, smulkiau nedetalizuojant, kokio tarybinio veikejjo pavardę jos paslëpè. 
kolektyvinis kūrejas - visa lietuvių tauta: įvairūs rašto, kultūros, visuomenès, politikos ir pan. veikejjai (jau minèti tiksliai įvardyti ir anoniminiai autoriai) bei tūkstančiai neįvardytų gyvosios kalbos informantų, kuriuos slepia konkrečių vietovių santrumpos.

\section{Rusija iliustraciniuose sakiniuose}

Iš iliustracinių sakinių ryškejja keli pagrindiniai RUSIJOS koncepto požymiai.

\subsection{Spalio revoliucijos atgarsiai}

Didelëje šalyje nuolat vyko visokių svarbių įvykių. Kartais iliustraciniuose sakiniuose jie nekonkretizuojami, tik pasakoma, kad šalyje kyla sujudimas, šaukiama ị kovą, kalbama apie artẻjančius didelius ịvykius, kurių atgarsiai pasiekia ir Lietuvą (žr. 1-3 sakinius).

(1) Visuomeninis sujudimas auga Rusijoje visoje liaudyje, visose jos klasèse rš (ž. sujudimas) ${ }^{19}$.

(2) Jaunosios Rusijos kovos šaukimas prasiskverbia net ị aklinai uždarytas kareivines rš (ž. kareivinès).

(3) Obelių apylinkes, kaip ir visa Lietuva, pasieke didžiujjų Rusijos j̣vykių aidas ř̌ (ž. aidas).

Vienas iš svarbesnių aptariamojo laikotarpio įvykių Rusijos istorijoje $\mathrm{XX}$ a. pradžioje kilusi revoliucija. Pastebima, kad šalyje vyko dvi viena po kitos revoliucijos (žr. 4 sakinị).

(4) Dviejų Rusijos revoliuciju patyrimo išnagrinẹjimas rš (ž. išnagrinèjimas).

Iliustraciniuose sakiniuose, kuriuose kalbama apie artėjančią revoliuciją, šalis metaforiškai lyginama su nëščia moterimi (žr. 5 sakinį), svarstoma, kas pirmieji pradèjo revoliuciją (žr. 6 sakinị), konkrečiai ịvardijama data, kada ji prasidejjo (žr. 7 sakinị).

(5) Rusija buvo néščia revoliucija daugiau nei bet kuri kita šalis rš (ž. nèščias).

(6) Rusijoje revoliucija, girdi, pradëję jūrininkai, tai ir Vokietijoje jūreivija, nusižiūrëjusi, èmusi riaušes kelti I. Simon (ž. jūreivija).

(7) 1905 metu sausio 9 dienq darbininkų kraujuje gimé pirmoji Rusijos revoliucija (sov.) rš (ž. kraujas).

19 Pavyzdžiai cituojami iš elektroninės LKŽe versijos (žr. www.lkz.lt). Santrumpų sąrašas pateikiamas straipsnio gale. Skliaustuose nurodomas žodis, iš kurio leksikografinio straipsnio imtas pavyzdys. 
Kalbama apie revoliucijos formas (žr. 8 sakinị), svarstoma, kokios buvo revoliucijos pasekmès Rusijai ir pan. (žr. 9 sakini).

(8) Kovos formos Rusijos revoliucijoje pasižymi milžinišku ịvairumu, palyginti su buržuazinemis Europos revoliucijomis rš (ž. įvairumas).

(9) Didžiosios Spalio socialistinès revoliucijos rezultatas buvo Rusijos iškritimas iš pasaulinès kapitalizmo sistemos (sov.) rš (ž. iškritimas).

Sovietiniais metais užrašytose iliustracijose pašiepiami ponai (žr. 10 sakinị), iškeliama partijos svarba (žr. 11 sakinị).

(10) Ponékams, pabègusiems nuo Rusijos revoliucijos kiauromis kelnemis, terūpi savo gerove (sov.) rš (ž. ponèkas).

(11) Mūsų partijos suvažiavimas buvo vienintelis tokios rūšies, neregètas reiškinys visoje Rusijos revoliucinio judëjimo istorijoje (sov.) rš (ž. reiškinys).

\subsection{Ekonomika, ūkis}

Apie Rusijos ekonomiką, ūkį LKŽe rasta visai mažai sakinių. Iš jų galima ši tą sužinoti apie Rusijoje buvusius mokesčius (žr. 12 sakinị), mažųuu ūkių gyvavimą (žr. 13 sakini).

(12) Jau ir dabar Rusijos arbatos uždas yra pats didžiausias pasaulyje rš (ž. uždas).

(13) Pačioje Rusijoje yra jau toki mažieji ūkiai, kurie už vištas ir kiaušinius tūkstančius rubliu išverčia Pt (ž. išversti).

Sovietiniais metais iš raštų išrašytuose sakiniuose kalbama apie šalyje nuolat didejjantị fabrikų skaičiu (žr. 14 sakinį), stambiosios pramonės plètimąsi ir pan. (žr. 15 sakinį).

(14) Fabriku skaičius Rusijoje didëja ir gana sparčiai didëja rš (̌̌. gana).

(15) Plieno išlydymas 1940 metais TSRS rytiniuose rajonuose 1,4 karto viršijo visos Rusijos 1913 metu plieno išlydyma rš (ž. išlydymas).

Fiksuota ir gana tuščių, lozungus primenančių pompastiškų sakinių (žr. 16 sakinį).

(16) Ekonomine Rusijos istorija tuo būdu jau ịrodè tai, kq rytoj ịrodys politine Rusijos istorija rš (ž. įrodyti).

Tokios iliustracijos apie augančią pramonę, gamybą, bandymą kažką įrodyti politikoje, siekimą išlaikyti statusą ir prestižą tarptautineje politikoje tik paliudija šiandienos istorikų ir politikų keliamą mintį, kad Rusija ir jos lyderiai šimtmečiais siekè ir tebesiekia „didžiosios valstybės statuso“ (Janeliūnas, Kojala 2016: 13). Šiandienos kontekste matyti, „kad „imperine““ retorika skamba visuose Rusijos politinio diskurso segmentuose“ (Malinova 2015: 273), o visa tai ataidi dar iš sovietinès imperijos laikų, kurie gana ryškiai atsispindi ir akademinio žodyno iliustraciniuose sakiniuose. 
Kiek kitaip Rusijos vaizdas atrodo šnektų atstovams. Lietuvai atgavus nepriklausomybę jau nebijoma pasakyti savo nuomonès apie skurdų žmonių gyvenimą Rusijoje (žr. 17-19 sakinius).

(17) O Rusijoj visi laukai tušti, ažužèlę, žmonès kaip vilkai vaikšto $\mathrm{Ob}$ (ž. vilkas).

(18) Visa Rusija išsivogta: vienas nuo kito vagia Jrb (ž. išvogti).

(19) Visq Rusija apëjau, tei[p], kai jie gyvena, niekur pasauly nèsu matęs Jrb (ž. visas).

\subsection{Ryšys su Lietuva}

LKŽe fiksuota nemažai sakinių, kuriuose kalbama apie Rusijos ir Lietuvos santykius. Abiejų šalių gyventojai nuolat migravo iš vienos šalies kitą. Iš šnektose užrašytų sakinių aiškejja, kad lietuviai dažniausiai į Rusiją bėgo ar pakliūdavo dèl karų (žr. 20 sakini), suiručiu (žr. 21 sakinị) ir pan.

(20) Jis per karą, sako, net Rusijon atsikliuvo Lš (ž. atkliūti).

(21) Kai pervertimai buvo, anas Rosijon išbègo Ob (̌̌. vertimas).

Kiti vykdavo į Rusiją dirbti ar gydytis (žr. 22-23 sakinius).

(22) Rusijo[je] b[uv]au pasitraukęs j Kazanę, dirbau Kazané[je] Žd (ž. patraukti).

(23) Jaunas talentuotas rašytojas humoristas Juozas Gurauskis, pačiame žaliume džiovos pakirstas, kankinasi kaži kokioje Rusijos sanatorijoje $\mathrm{Pt}$ (ž. žaliumas).

Lietuviams teko atlikti karinę tarnybą Rusijos armijoje (žr. 24 sakinį). Sovietmečiu užrašytame sakinyje su pasidžiavimu pabrèžiama, kad ị sovietinę armiją patekdavo geriausi Lietuvos jaunuoliai (žr. 25 sakini).

(24) Pradëjęs savo žygị Rusijos gilumoje, lietuviškas Tarybinès Armijos junginys nuëjo garbingų kovų ir pergalių keliq ligi Baltijos jūros pakrantès (sov.) sp (ž. junginys).

(25) Ji (Lietuva) atidavé savo jaunimo žiedą Rusijos armijai P. Klim (ž. žiedas).

Šnektose užrašytas ne vienas paliudijimas, kad žmonès ị Rusiją buvo išvežami per prievartą: minimi XIX a. pabaigos - XX a. pradžios trėmimai (žr. 26 sakinị), atkūrus Lietuvai nepriklausomybę ir išsivadavus iš aktyvios ir akylos sovietinès cenzūros žodyno tekste imami minèti ir masiniai gyventoju trèmimai 1940-1953 m. (žr. 27-28 sakinius).

(26) Per pirmajị kara buvau ị Rusija pavilkta - tris metus ir šešis mènesius Vlkš (ž. pavilkti).

(27) Septynių metų buvau vaikas, ka išvaré mumis ị Rusijq̨ Škn (ž. išvaryti).

(28) Vyrų daug išveže į Rusija, kame padoresnis ūkininkas, visus išvežè K1 (ž. vežti). 
Kai kuriuose iš šnektų ir raštų užrašytuose sakiniuose konkrečiai neįvardijama, kokiu metu ir dèl kokių priežasčių lietuviai pasitraukdavo ị Rusiją (žr. 29-31 sakinius).

(29) Ir anudu ketino jau traukties j Rusiją Krt (ž. traukti).

(30) Sūnus išbuvo aštuonis metus Rusijo[je] išvažiavęs Žlb (̌̌. išvažiuoti).

(31) Lietuvoje nieko neradęs, iškeliauja Rusijon ir ten amžinai nusèda rš (ž. nusèsti).

Vyko ir atgalinis judejjimas. Iš Rusijos ir į Lietuvą atvykdavo nemažai rusų, tikėdamiesi čia geresnio, kiek laisvesnio gyvenimo. Užsimenama, kad Lietuva rusus traukè kaip Amerika, čia jie gaudavo darbo (žr. 32-33 sakinius).

(32) Virto iš tos Rusijos čia an galvos, kaip ị Amerikq End (̌̌. virsti).

(33) Tai būdavo miško darbinykai vis suvažiavę iš kur, atvažiavę ar iš Rusijos, ar iš kur $\mathrm{Sb}$ (ž. suvažiuoti).

Iš iliustracijų matyti, kad ị Lietuvą iš Rusijos atvykdavo ištisos bendruomenès. Pavyzdžiui, sentikiai čia atsikèlè dèl persekiojimo Rusijoje (žr. 34 sakinį).

(34) XVII a. Lietuvoje atsirado dar vienos krikščionybès šakos išpažineju - sentikių. Jie atsikèle iš Rusijos, nes ten tuo laiku buvo smarkiai persekiojami MLTEIII60 (ž. sentikis).

Rusai ị Lietuvą vyko ne tik savo noru, bet buvo ir prievarta atvežami (žr. 35-36 sakinius).

(35) Any (rusai) privežta iš Rasiejaus Nmč (ž. privežti).

(36) Ventos tilta pri Mažeikių kad dirbo, buvo maskoliai iš Maskolijos atvežti su mediniais ratais Šts (ž. maskolis).

Vyko ne tik žmonių migracija. Iš Lietuvos ị Rusiją buvo gabenamos ìvairios prekès (žr. 37 sakini).

(37) Upeivos gabeno prekes $j$ Rusija Kin (ž. upeiva).

Iš Rusijos ị Lietuvą atkeliavo ne tik žmonès, bet ir ligos:

(38) Cholera buvo iš Rusijos (tada ji ten plètessi) užvežta Pt (ž. užvežti).

Ne vienoje iliustracijoje randame paliudijimą, kad Rytų ir Vakarų kryžkelejje esančią Lietuvą vis paliesdavo didžiosiose šalyse vykstantys ịvykiai. Pavyzdžiui, iš Vokietijos ị Rusiją nutiesti geležinkeliai ir keliai èjo per Kauną (žr. 39 sakinị); sudarius Rusijai ir Vokietijai taiką, ị Lietuvą galèjo grịžti karo pabègèliai (žr. 40 sakinị) ir pan.

(39) Kaunas vaidino labai svarbu strategini vaidmeni, nes pro ji èjo pagrindiniai geležinkeliai ir plentai iš Vokietijos $j$ Rusija MLTEII98 (ž. strateginis).

(40) 1918 metų kovo menesị sudarius taika tarp Tarybų Rusijos ir Vokietijos, i Lietuvą èmé grįžti karo pabègèliai rš (ž. tarp). 
Lozungus primenančiuose sakiniuose kalbama, kokią ittaką Rusijoje vykstantys ịvykiai darè Lietuvai (žr. 41 sakinị).

(41) Visoje Rusijoje sparčiai plètojantis kapitalizmui, Lietuvoje augo ir konsolidavosi darbininkų klasè (sov.) rš (ž. konsoliduoti).

\subsection{Idejos, partijos, valdininkai}

Sovietiniu laikotarpiu užrašytuose sakiniuose kalbama apie marksizmo, leninizmo idejas (žr. 42 sakinị); minimos publicistų, filosofų ir kt. visuomenės veikèjų (Visariono Belinskio, Aleksandro Gerceno, Nikolajaus Černyševskio ir kt.) pavardès (žr. 42-43 sakinius).

(42) Bielinskis, Gercenas savo mokslo, publicistikos ir meno veikalais paruoše dirva marksizmo-leninizmo idejoms Rusijoj prisiimti rš (̌̌. priimti).

(43) Černyševskis nesugebëjo, teisingiau, negalëjo dèl Rusijos gyvenimo atsilikimo pakilti iki Markso ir Engelso dialektinio materializmo (sov.) rš (ž. pakilti).

Keliuose sakiniuose kalbama apie kapitalizmą Rusijoje. Apie ji rašomos knygos (žr. 44 sakinị), ši socialinè ekonominè sistema Rusijoje ir augo, ir buvo griaunama (žr. 45-46 sakinius).

(44) Rašè knyga „Kapitalizmo išrutula Rusijoje“ rš (ž. išrutula).

(45) Rusijoje buvo likviduota senoji, kapitalistine bazè rš (ž. kapitalistinis).

(46) Panaikinus baudžiava, Rusijoje pradëjo sparčiai augti kapitalizmas rš (ž. kapitalizmas).

Sovietinio laikotarpio iliustracijose minimas komunizmas, pabrèžiama Rusijoje vykusios Spalio revoliucijos, pakeitusios geopolitinę situaciją Rytų ir Vidurio Europoje, svarba (žr. 47 sakinị).

(47) Spalio socialistine revoliucija Rusijoje nurodo visų šaliu proletarams keliq, kuriuo jie turi eiti i šviesu tiksla - komunizma (sov.) sp (ž. proletaras).

Apie Rusijoje veikiančias partijas kalbama iš raštu išrašytuose sakiniuose: minimi liberalai, socialdemokratai ir kt. (žr. 48-49 sakinius).

(48) Rusijos liberalai niekuomet nebuvo suorganizavę revoliucinés partijos kovai dèl patvaldystès nuvertimo rš (ž. liberalas).

(49) Rusijos socialdemokratai užsibrěže sau artimiausia politinị uždavini nuversti monarchija (sov.) rš (ž. monarchija).

Iš iliustracijų matyti, kad Rusijoje buvo daug visokiausių valdininkų, jie buvo siunčiami ị Lietuvą vykdyti ūkio ir kultūros sovietinimo (žr. 50 sakinị).

(50) Toji valdininkija buvo kaip tyčiomis suverbuota iš visos Rusijos rš (ž. suverbuoti). 


\subsection{Socialinès grupès}

LKŽe iliustraciniuose sakiniuose daugiausia dèmesio tenka valstiečiams. Pastebima, kad net panaikinus baudžiavą ju gyvenimas nebuvo lengvas (žr. 51-52 sakinius).

(51) Valstiečiu žemèvalda Rusijoje ..., tiek ir privatine (nuomotine ir pirktine žemè) ... apraizgyta senais, pusiau baudžiaviniais ryšiais ir santykiais (sov.) rš (ž. nuomotinis).

(52) $O$ iš ko susideda visa poreformine Rusijos istorija, jeigu ne iš masinio, niekur nematy to tokio intensyvaus valstiečì eksproprijavimo? rš (ž. masinis).

Sovietmečio iliustracijose akcentuojama, kad valstiečiai buvo labai stipri socialinė klasė, o kartu su darbininkais Rusijoje jie tapo revoliucijos varomąja jèga (žr. 53-54 sakinius).

(53) Lietuvos, kaip ir antrinès Rusijos imperijos dalies, narodnikai pagrindine revoliucijos jega laike valstiečius rš (ž. valstiečiai).

(54) Valstiečiai, gausingiausia priešrevoliucinès Rusijos klasè, iro, skilo $\dot{i}$ sluoksnius sp (ž. irti).

Rašant bei redaguojant žodyną sovietų laikais, nemažas dėmesys buvo skiriamas ir darbininkams, stengtasi pabrěžti, kad Rusijos istorijoje darbininkų klasè ne mažiau svarbi nei valstiečiai: Pirmajam pasauliniam karui einant ị pabaigą, ,darbininkai, paėmę valdžią kartu su vargingaisiais valstiečiais, turèjo stiprinti Tarybų Rusiją“ (Laurinavičius 1997: 53). LKŽe iliustracijos liudija, kaip panaikinus baudžiavą stiprèjo darbininkų savimonė (žr. 55 sakinị), jie aktyviai dalyvavo proletarinejje kovoje (žr. 56 sakini).

(55) Panaikinus baudžiava, Rusijoje sparčiais tempais augo kapitalizmas, formavosi ir telkèsi darbininkų klasé, stiprëjo jos klasinè savimonè sp (ž. savimonè).

(56) Proletariné kova apimdavo naujus darbininku sluoksnius ir plito visoje Rusijoje (sov.) rš (ž. proletarinis).

Apie kilmingųjų luomus LKŽe iliustracijoje beveik nekalbama. Fiksuotas tik vienas sakinys apie Rusijos imperijoje buvusią pareigybę - bajorų vadovą (žr. 57 sakinị).

(57) Bajory vadovas - Rusijos imperijos bajoru luomines organizacijos pareigūnas LTEI166 (ž. vadovas).

\section{6. Žmonių ir tautų padètis Rusijoje}

LKŽe randame šiek tiek informacijos apie ịvairių tautų gyvenimą Rusijoje. Pirmiausia konstatuojama, kad šalyje gyveno visokių tautų žmonių (žr. 58 sakini):

(58) Nacionaliniu atžvilgiu Rusija yra marga šalis rš (ž. šalis). 
Pripažistama, kad kitų šalyje gyvenančių tautų palaikymas buvo labai svarbus Rusijos pažangai (žr. 59 sakinị).

(59) Leninas nepaliaujamai kartodavo, kad be sqjungos su šiomis kitatautèmis masèmis Rusijos proletariatas negalès nugalèti (sov.) rš (̌̌. kitatautis).

Žodyno iliustracijose net neužsimenama apie ano meto Rusijos žmonių, tautų laisvę ar klestėimą. Šis faktas tik patvirtina Alexanderio Etkindo mintį, kad imperinè valstybė savo kontinentinejje teritorijoje vykdo „vidinę kolonizaciją“ ir mažiau išvystytoms teritorijoms nustato aiškų hierarchini santykị (Etkind 2011: 2).

Tačiau galima rasti užuominų apie Rusijoje stipriai veikusią cenzūrą (žr. 60 sakini):

(60) Tiktai pagalvokite, kaip reikia sužaloti šiq revoliucinę doktrina, kad ja būtu galima ịtalpinti ị Rusijos cenzūros Prokrusto lovą! rš (ž. įtalpinti).

Apie sovietiniais metais vykdytas represijas, masinius trèmimus, apskritai apie totalitarinę sovietų santvarką, tuo metu vyravusią baimę, prievartą sakiniuose su Rusija išvis nekalbama. Šis faktas dar syki parodo, kaip stipriai tuo metu žodyno rašytojus ir redaktorius veikė cenzūra. Akivaizdu, kaip tuo metu buvo svarbu iš informacinio lauko pašalinti nepageidaujamą informaciją, o atsiradusią tuščią erdvę užpildyti propagandiniu turiniu (plg. Sẻdaitytė 2017: 85). Iliustracijos apie realų, nepagražintą lietuvių gyvenimą sovietinès okupacijos sąlygomis, apie okupacinès valdžios ịtaką mūsų valstybès ir kiekvieno lietuvio gyvenimui pateko tik į žodyno Papildymų (LKŽP) ir Tarmių (LKŽT) kartotekas ${ }^{20}$.

\subsection{Gamta, mokslas, menas}

Rusijos didumas pabrèžiamas būdvardžiais gilus, didis, tolimas ir pan. (žr. 61 sakinị).

(61) Kai jis mirè, aš jau gyvenau tolimoj Rusijoj ir savarankiškai verčiaus farmacijos praktika A. Vien. (ž. praktika).

${ }^{20}$ Pastebėta, kad LKŽP fiksuota daug daugiau iliustracijų ne su vietovardžiu Rusija, o su etnonimu rusas. Tiriant tokių sakinių semantiką ryškèja ne tik lietuvių santykiai su konkrečios tautybès asmenimis, bet ir požiūris ị pačią Rusiją. Plg. LKŽe pateikiamą vieną iš ruso homonimų - 'Rusijos valdžia; Rusijos kariuomenë. LKŽP ir LKŽT iliustracijose, užrašytose Lietuvai atgavus nepriklausomybę, rusai ir jų įvesta santvarka, valdžia vertinami nepagražintai: Kur jau rusas užějo, jau ir užëjo (pasiliko ilgam) Antãlieptė (LKŽP 1998). Baisūs buvo laikai [pokaryje], užèjo rusas ir padarè [savo tvarka] Nemunẽlio Radviliškis (LKŽT 2009). Ar galëjo Lietuvèle atsilaikyti prieš rusą, prieš tokiq tautq̨? Nemunẽlio Radviliškis (LKŽT 2009). 
Tik 4 LKŽe iliustracijose kalbama apie Rusijos gamtą: minima Rytu Europos lyguma ir Rusijos skydas, pabrėžiama, kad Rusijoje yra derlingu dirvožemių (žr. 62-63 sakinius).

(62) Rusijos stepiu ir miškastepiu rajonai turi derlingiausia juodžemio dirvožemị rš (ž. miškastepè).

(63) Estijos žemès paviršius yra dalis didžiosios Rytų Europos lygumos Rusijos skydo EncVII1092 (ž. skydas).

Užsimenama, kad tai vejjuotas kraštas su labai šaltomis žiemomis (žr. 64-65 sakinius).

(64) Rusijo[je] tas i didliai vëjuotas kraštas Ms (ž. vejuotas).

(65) Ta žiema i Rusiją dideli šalčiai buvo, vokytis ir pašalo Sg (ž. vokytis).

LKŽe iliustracijose tik keliais žodžiais užsimenama apie Rusijos mokslą ir meną. Dviejuose sakiniuose minimi šios šalies klinikose dirbantys gydytojai ir bežiedžius augalus tyrinèjantys mokslininkai (žr. 66-67 sakinius).

(66) Geriausi Rusijos klinicistai visuomet kreipé demesị i skirtinga ivvairiu žmonių ligos eiga ir todèl moke ,gydyti ligonį, bet ne liga“ "rš (ž. klinicistas).

(67) Jis yra pirmasis Rusijoj kriptogamininkas, panaudojęs citologinį metoda grybams tirti J. Dag. (ž. kriptogramininkas).

Viename sakinyje kalbama apie archeologų tiriamą dantytosios keramikos kultūrą (žr. 68 sakinị).

(68) Ypač gražiai duobetosios-dantytosios keramikos kultūra yra pasireiškusi vidurio Rusijoje ir šiu dienu Suomijoje rš (ž. kultūra).

\section{Rusija reikšmių apibrèžtyse}

Rusija minima ne tik LKŽe iliustracijose, bet ir reikšmių apibrèžtyse, kurių turinys taip pat ne mažiau svarbus formuluojant bendrą RUSIJOS konceptą. Kalbininkai ne sykị yra pabrèžę, kad žodynuose pateiktos reikšmių apibrèžtys yra svarbus istorinės ir kultūrinès informacijos šaltinis (Skybina, Bytko 2015: 28tt), bemaž kiekviename žodyne ne tik iliustracijose, bet ir reikšmių apibrěžtyse galima rasti nemažai enciklopedinès informacijos (Kiefer 1988: 8; Wnęk, Bendoraitytė-Vnęk 2012: 82tt; Valančiauskienė 2019), nes „žodžiai ir pasaulis yra neatsiejami“ (Kirkness 2004: 60). Iš viso LKŽe rasta 71 reikšmès apibrèžtis, kurioje minima Rusija. Ši leksema pasitelkiama apibèžti 69 daiktavardžiams ir 2 būdvardžiams (baltas, rusinis). Pabrèžtina, kad net 33 reikšmių apibrèžtys susijusios su carine Rusija. Jos iš bendros imties elimintuotos ir šiame straipsnyje analizuojamos likusios 38 apibrèžtys, kurių turinys labiau sietinas su sovietiniu laikotarpiu.

Iš tiriamųju reikšmiu apibrèžčių išryškejja dar keli svarbūs RUSIJOS koncepto bruožai. 


\subsection{Svarbios Rusijos datos}

Keliose reikšmių apibrèžtyse minimos konkrečios datos. Iš reikšmių apibrěžčiu galima sužinoti, kad Rusijoje 1917 m. laikinosios vyriausybės galva tapo Kerenskis (̌̌. kerenka), 1917-1918 m. šalyje vyko ginkluotų darbininkų kova (̌̌. gvardija), o 1918-1920 m. vyko Rusijos pilietinis karas (ž. gvardija).

\subsection{Tautos, klasès, luomai}

Reikšmių apibrèžtyse minima keletas Rusijoje gyvenančių tautų: rùsai 'tauta, kalbanti viena rytų slavų kalbų, gyvenanti daugiausia Rusijoje', koriãkai 'tauta, gyvenanti Rusijoje (Kamčiatkoje ir Magadano srityje)' ir kt.

Be tautų, reikšmių apibrèžtyse minimos ir Rusijoje buvusios socialinès grupès: dvarininkai, valstiečiai (ž. atraižai), laisvieji žmonès, baudžiauninkai, tarnai, miesto varguomenè (̌̌. 2 kazokas).

\subsection{Kariuomenè, policija}

Žodyne Rusija minima apibrèžiant keletą su kariuomene ir policija susijusių terminų: milicija 'buvusioje TSRS ir dabar Rusijoje administracinè isstaiga visuomeniniam saugumui ir tvarkai palaikyti', rùsas 'Rusijos valdžia; Rusijos kariuomenë', ruskíejai 'Rusijos valdžia; Rusijos kariuomenè' ir kt.

\subsection{Srovès, judèjimai, partijos}

Didelèje šalyje formavosi ir veikẻ ịvairūs visuomeniniai, politiniai judejjimai ir srovès. LKŽe reikšmių apibrèžtyse minimas ekonomìzmas 'oportunistinè Rusijos socialdemokratų srovè, skelbusi, kad darbininkai turi kovoti tik dèl savo ekonominio būvio pagerinimo', nihilizmas 'nuo 1860 metų Rusijoje - rusų visuomeninès minties srovè, nukreipta prieš reakcinès bajorijos tradicijas, prieš bajorinès kultūros principus', narodnikỹste ‘Rusijos XIX amžiaus antrosios pusės smulkiosios buržuazijos visuomeninis-politinis judejjimas, idealizavęs valstiečių bendruomenę, neigęs vadovaujantį darbininkų klasès vaidmeni revoliucijoje’.

Apibrěžiami kai kurių organizacijų, partijų narių pavadinimai: bolševìkas 'Rusijos socialdemokratų darbininkų partijos revoliucinės daugumos narys', nihilistas 'nuo 1860 metų Rusijoje - nebajorų inteligentijos ${ }^{21}$ atstovas, neigiantis reakcinès bajorijos tradicijas, baudžiavinès ideologijos papročius' ir kt.

${ }^{21}$ İdomu tai, kad nei LKŽe iliustracijose, nei reikšmių apibrèžtyse su leksma Rusija daugiau nẻ karto nepaminèta inteligentija, o būtent inteligentijos sluoksnio atsiradimas yra „viena svabiausių prielaidų susiformuoti moderniai tautai“ (Aleksandravičius, Kulakauskas 1996: 224). 


\subsection{Piniginiai vienetai}

Kelios apibrèžtys skirtos sovietinėje Rusijoje cirkuliavusiems piniginiams vienetams pavadinti: kèrenka 'popierinis 20 ir 40 rublių vertès pinigas, išleistas Rusijoje 1917 m., kai laikinosios vyriausybės galva buvo Kerenskis', rùblis 'TSR Sąungos (ir ikirevoliucinès Rusijos) pagrindinis piniginis vienetas, lygus šimtui kapeikų; tos vertès piniginis ženklas' ir kt.

\section{Apibendrinimas ir išvados}

Ištyrus 118 LKŽe iliustracinių sakinių ir 38 reikšmių apibrèžtis, kuriose paminèta leksema Rusija, matyti, kad žodyne ryškiausiai atsispindi sovietmečio kolektyvinẻ lietuvių atmintis. Ji kuria tikrais įvykiais grịstą praeities aprašymą, kurị ne vieną dešimtmeti pasakojo daugybė žmonių (tarmių informantai ir rašytinių šaltinių autoriai), tačiau tas pasakojimas buvo labai stipriai paveiktas to meto viešojo sektoriaus sovietinès cenzūros ir žodyno informantų, autorių bei redaktorių vidinės savicenzūros. Kadangi šis žodynas nepildomas šiuolaikinių diskursų pavyzdžiais, šiame straipsnyje išanalizuoti duomenys leidžia nustatyti nuo Spalio revoliucijos iki XXI a. kalbos vartotojų sąmonejje verbalizuotą RUSIJOS konceptą.

Žodyno iliustracijose atsiskleidžia keli svarbūs RUSIJOS koncepto požymiai. Tai didelè šalis su šaltomis žiemomis, turinti lygumų, derlingų dirvožemių. Vienas iš svarbiausių to meto politinių įvykių - $1917 \mathrm{~m}$. vykusi spalio revoliucija, kuri pakeite geopolitinę situaciją Rytų ir Vidurio Europoje.

Didelèje daugiatauteje šalyje jos gyventojai ir ịvairios tautos nuolat migravo. Iš šnektose užrašytų sakinių aiškejja, kad dažniausiai ị šią šalį lietuviai bėgo dẻl karų, dalis lietuvių vyko ị šią šalį dirbti, gydytis, atlikti karinės tarnybos. Šnektose užrašyta liudijimų, kad žmonès į Rusiją buvo išvežami per prievartą. Minimi ankstesni (XIX a. pabaigos - XX a. pradžios) ir po Antrojo pasaulinio karo vykę masiniai gyventojų trèmimai. Iliustracijose kalbama ir apie atgalinị judejiimą. Iš Rusijos ir ị Lietuvą atvykdavo nemažai rusų: pavieniai rusai Lietuvoje gaudavo darbo, taip pat į Lietuvą iš Rusijos atvykdavo ir ištisos bendruomenès. Vyko ne tik žmonių migracija. Iš Lietuvos ir kitų šalių į Rusiją buvo vežamos įvairios prekès, o iš Rusijos atkeliaudavo ne tik žmonès, bet ir ligos.

Sovietinio laikotarpio iliustracijose ypač daug kalbama apie marksizmo, leninizmo, kapitalizmo, komunizmo ir kt. idejas, minimos to meto publicistų, filosofų ir kt. visuomenès veikèjų pavardès (Visariono Belinskio, Aleksandro Gerceno, Nikolajaus Černyševskio ir kt.), politinès partijos ir socialinès grupès. To meto iliustracijose pašiepiami ponai, iškeliama komunistų partijos 
svarba, kalbama apie Rusijoje nuolat didejjantị fabrikų skaičių, stambiosios pramonès plètimąsi ir pan. Dalis tokių sakinių skamba pompastiškai, primena lozungus. Rastos tik kelios iliustracijos apie Rusijos meną, mokslą. Taip pat sovietmečiu užrašytose iliustracijose net neužsimenama apie ano meto Rusijos žmonių ar tautų laisvę, klestėjimą, išvis nekalbama apie vykdytas represijas, masinius trèmimus, apskritai apie totalitarinę sovietų santvarką, tuo metu vyravusią baimę. Šie faktai aiškiai parodo, kaip stipriai tuo metu žodyno rašytojus ir redaktorius veikẻ sovietinè cenzūra ir kaip plačiai buvo vykdoma ideologinè kontrolè. Iliustracijos apie realų, nepagražintą lietuvių gyvenimą sovietinès okupacijos sąlygomis, apie okupacinės valdžios įtaką lietuvių gyvenimui pateko tik ị žodyno Papildymų bei Tarmių kartotekas.

Reikšmių apibrèžčių turinys taip pat ne mažiau svarbus formuluojant bendrą RUSIJOS konceptą. Iš tiriamųjų reikšmių apibrèžčių susidèlioja panašus RUSIJOS konceptas kaip ir iliustraciniuose sakiniuose, tik pastebėta, kad reikšmių apibrèžtyse daugiau konkretumo: čia nurodomos tikslios istorinès datos, minima daugiau Rusijoje gyvenančių tautų, socialinių grupių, luomų, srovių, judejjimų, partijų. Rusija minima apibrěžiant su kariuomene ir policija susijusius terminus bei piniginių vienetų pavadinimus.

Pastebėta, kad reikšmių apibrèžtyse pateikiami konkretūs, tikslūs su tiriamuoju objektu susiję faktai, o iliustracijose, be istorinio naratyvo, galima įžvelgti daugiau subjektyvumo, netgi emocingumo, kuris dažniausiai pasireiškia pirmuoju asmeniu užrašytuose sakiniuose.

\section{Straipsnyje vartotos Lietuvių kalbos žodyno vietovių ir rašytinių šaltinių santrumpos}

J. Dag - Jonas Dagys (1906-1993), jo raštai (botanika).

Enc - Lietuviškoji enciklopedija. I-IX tm. Kaunas 1933-1940. (Jei žodis enciklopedijoje ne antraštinis, skaitmenys rodo tomus ir skiltis.)

End - Endriejãvas, Klaipedos r.

Jrb - Jùrbarkas.

Kin - Kintaí, Šilutès r.

$\mathrm{K} 1$ - Kuliai, Plungès r.

P. Klim - Petras Klimas (1891-1969), jo raštai ir vadovèliai.

Kzt - Kazitiškis, Ignalinos r.

Lš - Liškiavà, Varènos $r$.

LTE - Lietuviškoji tarybinè enciklopedija, 1-12, Papildymai, Vilnius 1976-1985.

(Skaitmenys rodo tomus ir puslapius.)

MLTE - Mažoji lietuviškoji tarybinè enciklopedija, I-III tm. Lietuvos TSR Mokslu akademija. Vilnius 1966-1971. (Skaitmenys rodo tomus ir puslapius.)

Ms - Mósèdis, Skuodo r.

Nmč - Nemenčinè, Vilniaus r. 
$\mathrm{Ob}$ - Obẽliai, Rokiškio r.

Pt - Gabrielè Petkevičaitė-Bitè (1961-1943), jos raštai.

rš - raštų žodis ar sakinys.

$\mathrm{Sb}$ - Subãčius, Kupiškio $\mathrm{r}$.

$\mathrm{Sg}$ - Saũgos, Šilutès r.

I. Simon - Ieva Simonaityte (1897-1978), jos raštai.

sp - spaudos žodis ar sakinys.

Škn - Šakýna, Šiaulių r.

Šts - Šãtės, Skuodo r.

A. Vien - Antanas Vienuolis-Žukauskas (1882-1957), jo raštai.

Vlkš - Vilkỹškiai, Šilutès r.

Žd - Židìkai, Mažeikių r.

Žlb - Žlibinaĩ, Plungès r.

\section{Literatūra}

Aleksandravičius, Egidijus, Caru valdžioje. XIX a. Lietuva. Vilnius: Baltos lankos.

Kulakauskas, Antanas. 1996.

Bartmiński, Jerzy. 2007. Językowe podstawy obrazu świata. Lublin: Wydawnictwo UMCS.

Burinskaite, Kristina. 2005. Lietuvos ir Rusijos santykiai XV-XX a. Vilnius: Alma littera.

Etkind, Alexander. 2011. Etkind, Alexander. 2011. Internal Colonization: Russia's Imperial Expierience. Cambridge: Polity.

Gritenene, Aurelija. 2020. Koncept carskoj Rossii v «Slovare litovskogo jazyka». Aktual ni problemy sučasnoji osvity ta nauky $v$ konteksti jevrointehracijnoho postupu. Luc'k: Veža-Druk, 273-283.

Gritėnienè, Aurelija. 2016. Šrermukšnio vaizdinys „Lietuvių kalbos žodyne“. Tautosakos darbai 52, 85-104.

Gritėnienè, Aurelija. 2017. Žodyno vaizdinys Lietuvių kalbos žodyne. Bendrine kalba 90, 1-19. Prieiga internete: http://www.bendrinekalba.lt/?90.

Gudavičius, Aloyzas. 2009. Etnolingvistika: Tauta kalboje. Šiauliai: Šiaulių universiteto leidykla.

Gudavičius, Aloyzas. 2011. Reikšmè - sąvoka - konceptas ir prasmè. Res humanitariae 10, 108-119. Prieiga internete: http://etalpykla.lituanistikadb. lt/fedora/objects/LT-LDB-0001:J.04 2011 1367184173024/ datastreams/DS.002.0.01.ARTIC/content.

Janeliūnas, Tomas, Kojala, Struktūriniai veiksniai ir Rusijos užsienio politika: tapatybès Linas. 2016. naratyvų simuliacija V. Putino režime. Vilius Ivanauskas, Tomas Janeliūnas, Gražvydas Jasutis, Laurynas Jonavičius, Laurynas Kasčiūnas, Vytautas Keršanskas, Linas Kojala. Rusijos raidos scenarijai: implikacijos Lietuvos ir regiono saugumui. Vilnius: Rytų Europos studijų centras, 13-54.

Kiefer, Ferenc. 1988. Linguistic, Conceptual and Encyclopedic Knowledge: Some Implications for Lexicography. Prieiga internete: https://www. euralex.org/elx_proceedings/Euralex1988/005_Ferenc_Kiefer_ Linguistic, Conceptual and Encyclopedic Knowledge - Some Implications for Lexicography.pdf 
Kirkness, Alan. 2004.

Kruopas, Jonas. 1948.

LKŽe =

LKŽ instrukcija. 1980.

Malinova, Olga. 2015.

Naktiniené, Gertrūda. 2012.

Nepokupnas, Anatolijus. 2002.

Nowak, Andrzej. 2015.

Papaurèlytė-Klovienè, Silvija. 2007.

Rutkovska, Kristina,

Smetona, Marius,

Smetoniené, Irena. 2017.

Sèdaitytè, Edita. 2017.

Skybina, Valentyna, Bytko, Nataliya. 2015.

Smetonienè, Irena. 2019.

Subačius, Paulius. 1999.

Šimènaite, Zita. 2010.

Tamulionienè, Aurelija. 2003.
Lexicography. The Handbook of Applied Linguistics. Ed. Alan Davies and Catherine Elder. Blackwell Publishing Ltd., 54-82. Lietuvių kalbos žodynas. Tarybine mokykla 12, 45-46.

Lietuviu kalbos žodynas (t. I-XX, 1941-2002): elektroninis variantas. Redaktorių kolegija: Gertrūda Naktinienè (vyr. redaktorè), Jonas Paulauskas, Ritutè Petrokienè, Vytautas Vitkauskas, Jolanta Zabarskaitè. - Vilnius: Lietuvių kalbos institutas, 2005 (atnaujinta versija, 2008 ir 2018). Prieiga internete: www.lkz.lt.

„Lietuvių kalbos žodyno“ instrukcija. Vilnius: Lietuvių kalbos ir literatūros institutas.

Kolektyvinès praeities ideja posovietineje Rusijoje: savivaizdis ir imperijos palikimas. Atminties kultūrų dialogai Ukrainos, Lietuvos, Baltarusijos (ULB) erdveje. Sud. Alvydas Nikžentaitis ir Micał Kopczyński. Vilnius: Lietuvos istorijos institutas, 257-275.

Elektroninio Lietuvių kalbos žodyno naujovès. Kalbos kultūra Nr. 85, 92-102. Prieiga internete: http://old.lki.lt/LKI_LT/ images/Periodiniai_leidiniai/Kalbos_kultura/Straipsniai/085/ KK_85_092_102_Naktiniene.pdf

Žodynas - tai abècèlès tvarka išdèstytas visas pasaulis Lietuvoje ir Lietuva visame pasaulyje. Seimo kronika: specialus Nr. 22 (228), 1421. Prieiga internete: http://www6.lrs.lt/kronikos/ pdf/030101/k-22.pdf.

Imperija rusų politiniame diskurse po 1991 metų. Atminties kultūru dialogai Ukrainos, Lietuvos, Baltarusijos (ULB) erdvejje. Sud. Alvydas Nikžentaitis ir Micał Kopczyński. Vilnius: Lietuvos istorijos institutas, 276-289.

Lingvistinès kultūrologijos bruožai. Šiauliai: Vš Šiaulių universiteto leidykla.

Vertybès lietuvio pasaulèvaizdyje. Vilnius: Akademinė leidyba.

Sovietinès cenzūros istoriografija: pagrindinès tyrimų kryptys ir cenzūros sampratos. Knygotyra 69, 84-102. Prieiga internete: https://epublications.vu.lt/object/elaba:24603698/24603698. pdf

Encyclopedic definitions in language dictionaries - a treasure of culture. Logos et Littera: Journal of Interdisciplinary Approaches to Text. Podgorica: University of Montenegro, 28-44.

Išmintis lietuvio pasaulèvaizdyje. Problemos 95, 130-143.

Lietuvių tapatybès kalvé. Vilnius: Aidai.

Lietuvių ir lenkų leksikografijos sąsajos (Związki leksykografii polskiej i litewskiej). Językowe i kulturowe dziedzictwo Wielkiego Księstwa Litewskiego. Red. nauk. Jolanta Mędelska, Zofia Sawaniewska-Mochowa. Bydgoszcz: Wydawnictwo Uniwersytetu im. Kazimierza Wielkiego, 158-166.

„Lietuvių kalbos žodyno“ I ir II tomo ideologinių taisymų nuostatos. Žmogus ir žodis, t. 1, Nr. 5, 63-69. 
Umbrasas, Alvydas. 2019. Valančiauskienè, Aušra. 2019.

Vitkauskas, Vytautas. 2002.

Wnęk, Piotr, BendoraitytèVnęk. 2012.

Zabarskaitè, Jolanta. 2010.

Zabarskaitè, Jolanta. 2012.

Zabarskaitė, Jolanta. 2019.

Žukas, Vladas. 2005.

Aurelija Griteniene

Lietuviu kalbos institutas

P. Vileišio 5, LT-10308 Vilnius, Lietuva

aurelija.genelyte@gmail.com
Terminologija Lietuvių kalbos žodyne. Terminologija 26, 162-183. Enciklopedinès žinios dvikalbiuose žodynuose: geografijos sritis. Verbum 10. Prieiga internete: https://www.zurnalai.vu.lt/ verbum/article/download/16486/15670/27131.

Didysis akademinis mūsų Žodynas. Dvidešimt „Lietuvių kalbos žodyno" tomu. Sud. Jolanta Zabarskaitè, Zita Šimėnaitè, Vilnius: Lietuvių kalbos institutas, 8-14.

Encyclopedic and linguistic information in dictionaries. Daugiakalbystès tyrimai. Sud. Nemira Mačianskienè. Kaunas: Vytauto Didžiojo universiteto leidykla, 82-91.

Politinis pasaulèvaizdis didžiajame „Lietuvių kalbos žodyne“ (valstybè, ịstatymas, valdžia). Parlamento studijos 9, 126-143. Prieiga internete: http://www.parlamentostudijos.lt/Nr9/9_ kalba_1.htm.

Kitoks didžiojo „Lietuvių kalbos žodyno“ skaitymas: Adalbertas Bezzenbergeris, marios, pamarys, pamariškis. Mažoji Lietuva: paribio kultūros tyrimai. Sud. Grasilda Blažienė, Nadežda Morozova, Jolanta Zabarskaitė. Vilnius: Lietuvių kalbos institutas, 239-271.

Rusijos federacijos prezidento V. Putino naratyvų ideologiniai mechanizmai Lietuvos internetinèje žiniasklaidoje. Parlamento studijos 27, 76-118. Prieiga internete: http://www.parlamentostudijos.lt/Nr27/files/76-118.pdf.

Kostas Korsakas: prisiminimai. Vilnius: Ogamas.

\section{KOPSAVILKUMS}

\section{Krievija vārdnīcas Lietuvių kalbos žodynas ilustratīvajos teikumos un nozīmju definīcijās}

\section{Aurelija GRITÉNIENĖ}

Rakstā analizēts, kāds KRIEVIJAS koncepts veidojas no vārdnīcas „Lietuvių kalbos žodynas“ ilustratīvajiem teikumiem un nozīmju definīcijām, kurās pieminēta leksēma Rusija 'Krievija'. Raksta mērḳis ir noteikt, kuras koncepta iezīmes ir vissvarīgākās un kāda varētu būt Krievijas kognitīvā definīcija. Kopumā rakstā analizētas 118 ilustratīvu teikumu un 38 nozīmju definīcijas. Pētījuma materiāls tika savākts no elektroniskās vārdnīcas teksta, neņemot vērā jaunākos pielikumu datus un dialektu kartotēkas, tāpēc jāuzsver, ka iegūtie rezultāti atspoguḷo KRIEVIJAS konceptu, kas veidojies lietuviešu pasaules uzskatā kopš 1917. gada oktobra revolūcijas līdz 21. gadsimtam. Empīriskais materiāls pētīts ar semantisko analīzi, interpretējošo un aprakstošo metodi.

Izpētot ilustratīvos teikumus un nozīmju definīcijas, kurās pieminēta leksēma Rusija, redzams, ka vārdnīca atspoguḷo padomju laika lietuviešu kolektīvo atmiņu. Veidojas reālos 
notikumos balstīts pagātnes apraksts, kuru gadu desmitiem ir stāstījuši daudzi cilvēki (izlokšnu informanti un rakstisko avotu autori), taču šo stāstu ḷoti spēcīgi ir ietekmējusi vārdnīcas autoru un redaktoru (paš)cenzūra.

Vārdnīcas ilustrācijas atklāi vairākas svarīgas KRIEVIJAS koncepta iezīmes. Tā ir liela valsts ar aukstām ziemām, ar līdzenumiem un auglīgu augsni. Viens no svarīgākajiem sava laika politiskajiem notikumiem bija 1917. gada Oktobra revolūcija. Ilustrācijās ir daudz runāts par iedzīvotāju un dažādu tautu migrāciju. No izloksnēs pierakstītajiem teikumiem var uzzināt, ka visbiežāk lietuvieši bēguši uz Krieviju karu dēḷ, daḷa lietuviešu devušies uz šo zemi strādāt, àrstēties vai karadienestā. Izloksnēs pierakstītas arī liecības, ka cilvēki tikuši ar varu izsūtīti uz Krieviju. Ilustrācijās runāts arī par migrāciju pretējā virzienā. Daudzi krievi ieradušies Lietuvā, lai te strādātu vai dzīvotu.

Padomju perioda ilustrācijās ḷoti daudz runāts par marksismu, ḷeņinismu, kapitālismu, komunismu u. c. idejām, minēti tā laika publicistu, filozofu u. c. sabiedrisko darbinieku uzvārdi, politiskās partijas un sociālās grupas, izsmieti kungi, izcelta komunistiskās partijas nozīme, runāts par arvien pieaugošo rūpnīcu skaitu, smagās rūpniecības paplašināšanos Krievijā utt. Daudzi no šiem teikumiem izklausās pompozi, atgādinot saukḷus.

Nozīmju definīciju saturam ir ne mazāka nozīme, formulējot KRIEVIJAS vispārējo konceptu. Definīcijas ir precīzākas: šeit ir norādīti precīzi vēsturiskie datumi, pieminēts vairāk Krievijā dzīvojošo tautu, sociālo grupu, politisko strāvu, kustību un partiju. Krievija ir minēta ar armiju un policiju saistìtu terminu definīcijā un naudas vienību nosaukumos.

Novērots, ka nozīmju definīcijas sniedz precīzus faktus par pētāmo objektu, bet ilustratīvajos teikumos papildus vēsturiskajam naratīvam var pamanīt vairāk subjektivitātes, pat emocionalitātes, kas parasti izpaužas pirmajā personā pierakstītos teikumos.

\section{SUMMARY}

\section{Russia in Illustrative Sentences and Definitions of the Dictionary of the Lithuanian Language}

\section{Aurelija GRITĖNIENĖ}

The article analyses the concept of RUSSIA that can be pieced together from the illustrative sentences and definitions present in the Dictionary of the Lithuanian Language Lietuviu kalbos žodynas that contain a reference to the lexeme Rusija 'Russia'. The goal here is to determine the key attributes of this concept and the possible cognitive definition of Russia. The article covers a total of 118 illustrative sentences and 38 definitions of meanings. Material for the study was screened in the electronic version of the Dictionary, disregarding the latest data available in the card indices of New Additions and Dialects, making it critical to accentuate that the results of the study reflect the concept of RUSSIA that took shape in the Lithuanians' attitude from the 1917 October revolution till the $21^{\text {st }}$ century. Empiric material is scrutinised using the methods of semantic analysis, interpretation, and description.

Analysis of the illustrative sentences and definitions of meanings containing the lexeme Russia shows that the Dictionary provides a reflection of the Soviet period collective memory of the Lithuanians. It projects an account of the past grounded in real events that have been narrated by many people (dialectal informants and authors of written sources) for decades; however, this tale has been heavily influenced by the (self-)censorship of the authors and editors of the Dictionary of that period. 
The illustrations of the Dictionary reveal a number of key attributes of the concept of RUSSIA. It is a vast country with cold winters, flats, and fertile soil. One of the watershed political events of that era was the 1917 October revolution. The illustrations carry a great deal of information about the migration of people and different nations. Dialectal sentences inform us that Lithuanians would often flee to Russia driven by wars; some Lithuanians travelled to that country in pursuit of work, medical treatment, military service. Dialects bear testimony to the fact that people would be taken to Russia by force. The illustrations speak of people moving in the opposite direction as well. There are quite a number of Russians coming from Russia to work or live in Lithuania.

Illustrations from the Soviet period emphasize he ideas of Marxism, Leninism, capitalism, communism, etc., mention the names of publicists, philosophers, and other public figures, political parties and social groups of the era, mock the upper class, elevate the importance of the Communist Party, speak about an ever-growing number of factories in Russia, the expansion of heavy industry, and so on. Some of these questions sound pompous and resemble catchwords.

The content of the definitions of meanings is equally important when it comes to formulating the overall concept of RUSSIA. The definitions of meanings carry a higher degree of specifics, indicating precise historical dates, mentioning more nations living in Russia, as well as political trends, movements, and parties. Russia is referred to in definitions of terms relating to the military and the police, as well as the names of monetary units.

It has been noted that the definitions of meanings provide precise facts pertaining to the subject of the study, while illustrations, apart from the historical narrative, possess a higher degree of bias and even emotion, which is usually expressed through sentences written in first person. 